\title{
Population genetics of the moss Plagiothecium undulatum (Hedw.) Schimp. I. Inheritance of allozymes
}

\author{
ANNELIES HOFMAN, WILKE VAN DELDEN \& BEN O. VAN ZANTEN* \\ Department of Genetics and "Department of Plant Ecology, University of Groningen, P.O. Box 14, 9750 AA Haren, \\ The Netherlands.
}

\begin{abstract}
Twenty-one allozyme loci were assayed in a subpopulation of the dioecious moss Plagiothecium undulatum. Six loci were polymorphic and could be used to demonstrate the different expression of allozymes at the haploid gametophytic and diploid sporophytic life stage. Progeny analysis on sporelings derived from heterozygous sporophytes revealed that for Gpi-2, Pgm-1 and Icd-1 the maternal and paternal genotypes segregated in a simple 1:1 ratio. The possibilities of gene duplications for Pgm and Icd in P. undulatum are discussed.
\end{abstract}

Keywords: allozymes, bryophytes, gene duplication, progeny analysis.

\section{Introduction}

Relatively little information is available on the population genetics of bryophytes. Basic knowledge about population structure and dynamics is sparse for many species (Meagher \& Shaw, 1990) despite the fact that mosses offer a particularly interesting comparison with higher plants, as they have a life-history in which the dominant phase is genetically haploid. Consequently in this extended gametophytic phase there is no opportunity for new mutations to be shielded from natural selection in a heterozygous condition (Longton, 1976) and no overdominance is possible.

In dioecious moss species male and female gametangia (antheridia and archegonia respectively) occur on separate plants (gametophytes). Gametes are produced through mitotic divisions. When sufficient water is available and distances between plants of the opposite sex are small enough, the spermatozoids can reach and fertilize the egg cells. Spermatozoids are mainly dispersed by passive transport in rain water because their swimming capacity is limited (Muggoch \& Watton, 1942). The zygote that results from the fusion is the onset of the diploid sporophytic generation. As the sporophyte matures, spore mother cells within the sporangium undergo meiosis, resulting in haploid spores, which are discharged in dry weather. The germinating spore produces a filamentous protonema on which buds develop that grow into leafy gametophytic shoots.

The continuous physical association of the sporophytes with their maternal gametophytes (this in contrast with ferns), and the fact that each sporophyte is the result of one single fertilization, makes mosses ideal objects for genetic study. Electrophoretic analysis of a maternal gametophyte and its accessory sporophyte enables the deduction of the paternal genotype. Despite these obvious advantages (Cove, 1983), few formal genetic studies involving crossing experiments in bryophytes have been undertaken since the early studies of Von Wettstein $(1923,1924)$. The main reason for this is that it is very difficult to make controlled crosses. More recently Grimsley et al. (1977a,b, 1980) and Ashton et al. (1988) have studied sexual crossing and somatic hybridization by protoplast fusion of mutant strains of Physcomitrella patens, to analyse the segregation of certain induced mutations. In this way they were able to ascertain the dominance status of mutant alleles and to investigate linkage relationships between the genes involved.

As part of a larger study of the population genetics of the genus Plagiothecium, it was desirable to make controlled crosses between electrophoretically distinct phenotypes, to provide a sound basis for the genetic interpretation of electrophoretic patterns. For this purpose a dioecious species was selected to circumvent the 
difficult task of preventing self-fertilizations in monoecious species. The lateral position and the small size of the gametangia in this pleurocarpous genus highly restrain the experimental crossing of different genotypes. The induction of controlled crosses by transplanting moss clumps of the opposite sex and different multilocus genotypes into a mosaic pattern, under semi-natural circumstances, was unsuccessful. We tried therefore to demonstrate cross-fertilizations in a natural, polymorphic population, and subsequently to rear sporelings from heterozygous sporophytes. The latter approach is troublesome, dioecious mosses generally fruit much less frequently than monoecious species (Smith, 1978; Longton \& Schuster, 1983). The spatial segregation of sexes into unisexual clumps (due to extensive vegetative reproduction) may be an important factor limiting spermatozoids from reaching archegonia. The differences in the enviromental control of antheridial production and archegonial production (Newton, 1972), as well as a high ratio of sterile to sexually differentiated plants (Stoneburner, 1979), may further restrict sexual reproduction in dioecious populations.

This phenomenon occurs also in the genus Plagiothecium. The dioecious species $P$. undulatum has rarely been recorded fruiting in The Netherlands (Touw \& Rubers, 1989). However, a population of this species was recently discovered with numerous sporophytes. Detailed electrophoretic analysis revealed a high level of genetic variation and microscale hetero-

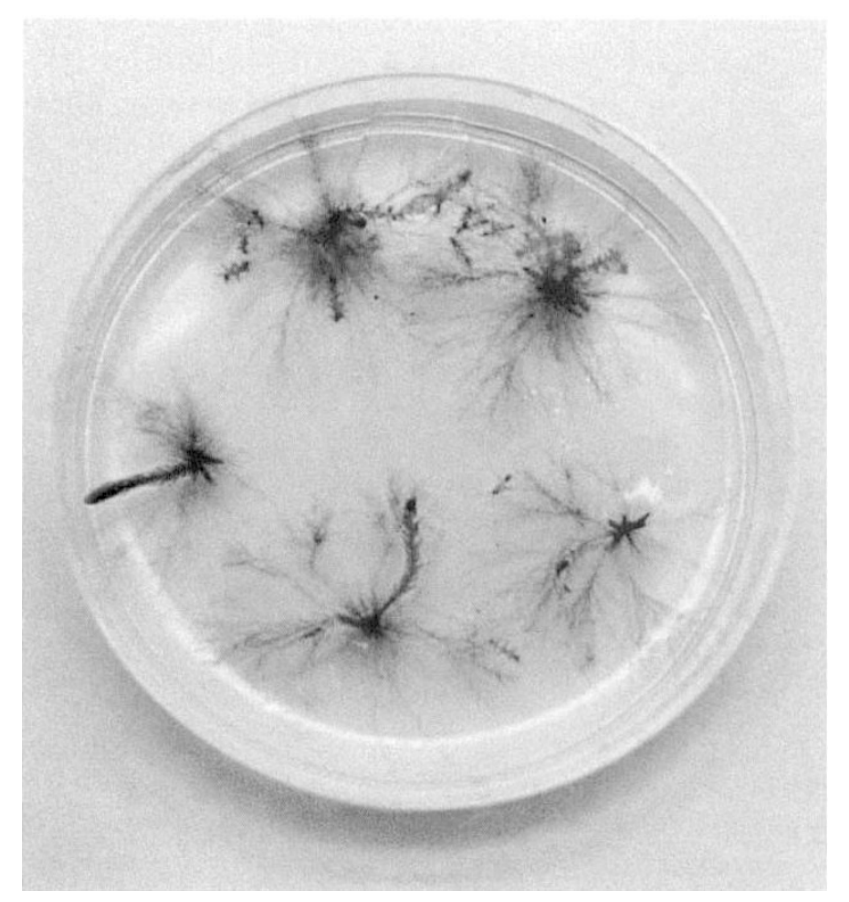

Fig. 1 Sporelings 7 months after spore germination. geneity in this population (A. Hofman, in preparation). The aim of the present study is to use these characteristics to ascertain the Mendelian inheritance of allelic variants of isozyme loci, and to show the different genetic expression of allozymes at the distinct life stages due to the alternating ploidy levels.

\section{Materials and methods}

\section{Sampling}

To demonstrate the diploid expression of allozymes in the sporophytic stage, very young sporophytes were collected (May, 1989) from a plot of $50 \times 50 \mathrm{~cm}$, from a continuous carpet of $P$. undulatum in the Asserbos (NE Netherlands). A number of sporophytes was left on the site to mature further to be used for the analysis of allozyme inheritance in their progeny. For this purpose eight mature sporophytes with intact opercula were collected, attached to their maternal gametophytes (July, 1989).

\section{Spore germination and development}

The surfaces of mature capsules were sterilized and after removal of the operculum, the spores were scattered on Petri dishes $(\varnothing 9 \mathrm{~cm})$ containing autoclaved medium of Murashige \& Skoog (1962) with 0.8 per cent agar. The dishes were sealed with strips of parafilm. The sowing procedure was carried out in a laminar air flow bench and after removal from the sterilizing solution (see Allsopp \& Mitra, 1958) the capsules were handled with sterilized instruments only. Mean ( $n=88-112)$ spore diameter was measured by examining one drop of spore suspension from each capsule at a magnification of $400 \times$. After 2 months the germination percentage was scored and the sporelings were transferred to fresh agar plates $(\varnothing 5 \mathrm{~cm})$. To be able to distinguish gametophytes which had developed from single spores, five sporelings per Petri dish were planted well apart. Seven and a half months after sowing the first gametophytes were large enough to be analysed electrophoretically (Fig. 1).

\section{Electrophoresis}

Horizontal starch gel electrophoresis was performed as described by Hofman (1988a). The loci coding for one particular enzyme system were numbered sequentially and their alleles denoted alphabetically in decreasing order of anodal electrophoretic mobility. A detailed electrophoretic study of the plot from which the sporophytes were taken ( 21 presumptive loci; A Hofman, in preparation) has revealed that the following enzyme 
systems are polymorphic (locus abbreviations in brackets, followed by the letter designating the most common allele and its frequency in the gametophytes of that particular plot): glucose phosphate isomerase (Gpi-2, c: 0.85), phosphoglucomutase (Pgm-1 b: 0.70; $P g m-3$, b: 0.96), triose phosphate isomerase (Tpi-1, a: $0.80 ;$ Tpi-2, b: 0.69) and isocitrate dehydrogenase (Icd1, a: 0.92). Young sporophytes, sporelings and their associated maternal gametophytes were analysed for these polymorphic loci on a tris-citrate buffer system $(0.1 \mathrm{M}, \mathrm{pH} 7.0)$. Care was taken to remove all haploid tissue (calyptra, perichaetal leaves) from the sporophytes before crushing them for enzyme extraction.

\section{Results}

\section{Electrophoretic patterns observed in gameto- phytes of the subpopulation}

In the $50 \times 50 \mathrm{~cm}$ plot from which the sporophytes were collected, the gametophytes were polymorphic for the loci Gpi-2, Pgm-1, Pgm-3, Tpi-1, Tpi-2 and Icd1. Gpi-2 was triallelic in this subpopulation, and the other five loci were diallelic. Gpi-2 and Pgm-3 gave a single band of strong activity (see Fig. 2). Pgm-1 had a two-banded zone of somewhat weaker activity. Both Pgm-1 bands were equal in activity, and mobility differences invariably involved both bands changing in concert (see Fig. 3). Tpi-1 and -2 both gave one band of strong activity, each with a weaker extra band, which consistently varied in concert with the strong band. Staining for isocitrate dehydrogenase always gave either one single or three bands of activity. The inter-
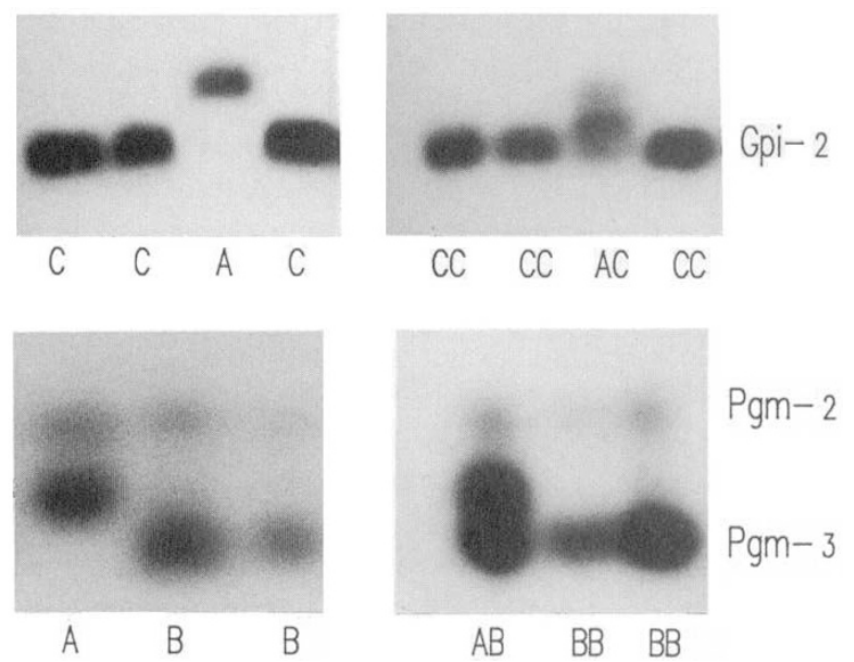

Fig. 2 Electrophoretic phenotypes of maternal gametophytes (on the left) and their corresponding sporophytes (on the right, in the same order). Top: Gpi-2. Bottom: Pgm-2 and -3 . Genetic interpretation of the patterns of $\mathrm{Gpi}-2$ and $P g m-3$ is presented below the gels. pretation of this pattern will be addressed in the discussion.

\section{Diploid expression of allozymes in the sporophytic phase}

When a female gamete is fertilized by a male gamete which carries a different allele at one of the polymorphic loci assayed in this study, this leads to a heterozygous pattern for that particular locus during electroporesis of the resulting sporophyte.

Figure 2 (top) shows the result of fertilization of a female $P$. undulatum plant with a deviant allele (a) at the Gpi-2 locus, by a male plant carrying the most common allele (c). From the banding pattern observed in the heterozygous sporophyte (ac) it can be concluded that GPI is a dimeric enzyme, displaying a heterodimeric band in the heterozygous sporophyte. Figure 2 (bottom) also shows the fertilization of a female plant with a deviant genotype at the Pgm-3 locus (a), by a male plant with the most common allele (b). In this case it can be deduced that PGM is a monomeric enzyme.

The sporophyte is the only stage at which the subunit structure of the enzymes can be derived from the heterozygous pattern. In this way it was also deduced that TPI (and probably ICD) is/are dimeric.

Table 1 Results of electrophoretic analysis of sporelings from capsule 1 and capsule 2 . The observed segregation ratio was tested against an expected $1: 1$ ratio, using the $G$-test for goodness of fit

\begin{tabular}{lllll}
\hline & Maternal & $\begin{array}{l}\text { Deduced } \\
\text { paternal } \\
\text { genotype }\end{array}$ & $\begin{array}{l}\text { Observed } \\
\text { genotypes } \\
\text { in offspring }\end{array}$ & $\begin{array}{l}G \\
(1 \mathrm{~d} . \mathrm{f} .)\end{array}$ \\
\hline Capsule 1 & & & & \\
Gpi-2 & B & C & $15 \mathrm{~B}: 12 \mathrm{C}$ & $0.334 \mathrm{~ns}$ \\
Pgm-1 & A & B & $6 \mathrm{~A}: 8 \mathrm{~B}$ & $0.287 \mathrm{~ns}$ \\
Pgm-3 & B & B & $27 \mathrm{~B}$ & - \\
Tpi-1 & A & A & $27 \mathrm{~A}$ & - \\
Tpi-2 & B & B & $27 \mathrm{~B}$ & - \\
Icd-1 & A & A & $27 \mathrm{~A}$ & - \\
Capsule 2 & & & & \\
Gpi-2 & C & C & $33 \mathrm{C}$ & - \\
Pgm-1 & B & B & $33 \mathrm{~B}$ & - \\
Pgm-3 & B & B & $33 \mathrm{~B}$ & - \\
Tpi-1 & A & A & $33 \mathrm{~A}$ & - \\
Tpi-2 & B & B & $33 \mathrm{~B}$ & - \\
Icd-1 & B & A & $15 \mathrm{~A}: 18 \mathrm{~B}$ & $0.273 \mathrm{~ns}$ \\
\hline
\end{tabular}

ns = not significant. 


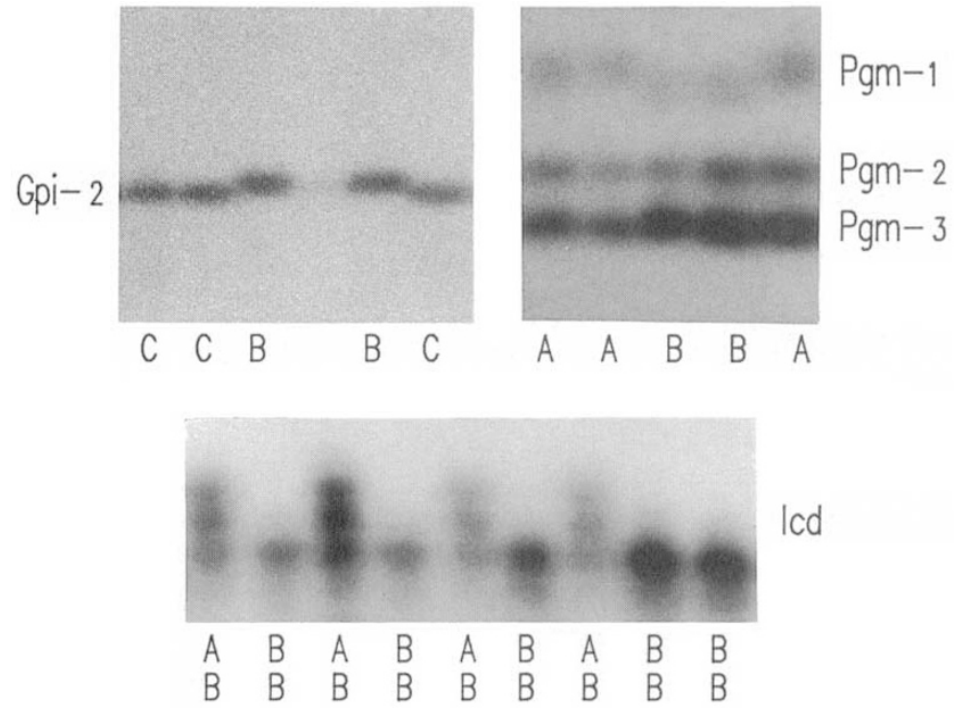

Fig. 3 Electrophoretic phenotypes observed in progeny from capsule 1 (top, GPI and PGM) and capsule 2 (bottom, ICD). Genetic interpretation of the pattern for Gpi-2 and Pgm-1 in sporelings from capsule 1 is given below the two gels at the top, and for $I d c-1$ (upper row) and $I c d-2$ (lower row) in sporelings from capsule 2 below the gel at the bottom (see also Discussion for interpretation of $I c d$ ).

\section{Segregation of allozymes in progeny derived from heterozygous sporophytes}

Sporelings obtained from two capsules and their maternal gametophytes were analysed for the six loci polymorphic in this subpopulation. From the electrophoretic patterns observed in the maternal gametophyte and the offspring the paternal genotype could be deduced (Table 1). The spores of the other six capsules which were collected did not germinate, probably because the spores were not fully ripe, or because these capsules were slightly damaged and the spores were killed during surface sterilization of the capsule. The 27 sporelings from capsule number 1 displayed two variants at the Gpi-2 and Pgm-1 locus (Fig. 3, top). The 33 sporelings of capsule number 2 varied at the $I c d-1$ (Fig. 3, bottom). The observed numbers of these variants are given in Table 1 . Under the assumption that the parental gametophytes are genetically haploid, a simple 1:1 segregation of the maternal and paternal genotype is expected in the offspring. The observed ratios were tested against the ratio expected under this Mendelian inheritance model, using the $G$-test for goodness of fit (Sokal \& Rohlf, 1981). No significant deviations from expectation were found (Table 1).

\section{Linkage}

The 14 sporelings from capsule 1, for which Pgm-1 could be scored, permitted a test for linkage with the Gpi-2 locus. All four possible allele combinations for Gpi-2/Pgm-1 were observed in the offspring in about equal frequencies $(\mathrm{b} / \mathrm{a}: \mathrm{b} / \mathrm{b}: \mathrm{c} / \mathrm{a}: \mathrm{c} / \mathrm{b}=3: 4: 3: 4)$. Therefore $P g m-1$ and $G p i-2$ seem to mark two distinct linkage groups.

\section{Germination percentage and spore size}

For both intact capsules the spore germination percentage approximated $90 \%$. Spore sizes ranged from 10 to $16 \mu \mathrm{m}$. There was no significant difference in mean spore sizes in both capsules: $14.0 \mu \mathrm{m}$ (S.E. 0.246) and $13.7 \mu \mathrm{m}$ (S.E. 0.241), respectively. The spore size measurements displayed a normal distribution in each capsule. This indicates that there is no difference in size between male and female-determining spores.

\section{Discussion}

The results presented here demonstrate that the observed phenotypic electrophoretic variation in Plagiothecium has a simple genetic basis, and can be attributed to allelic differences at allozyme loci. Similar results for one enzyme system were obtained in liverworts by Zielinsky $(1984,1986)$. In order to estimate the outcrossing rates in the monoecious Pellia epiphylla (Zielinsky, 1984) P. borealis (Zielinsky, 1986) he analysed the progenies from different sporangia for peroxidase. A 1:1 segregation of two peroxidase phenotypes was observed in progenies from sporangia which were the results of (demonstrable) cross-fertilizations. Recently Innes (1990) published an electrophoretic study on the microgeographic differentiation within a population of the moss Polytrichum juniperinum. Although no progenies of single sporangia were analysed, Innes (1990) was able to deduce paternal genotypes after electrophoresis of sporophytes and their maternal gametophytes.

In the current study evidence is also presented on the subunit structure of some enzymes in bryophytes. In the diploid sporophytic stage the genes of both 
parents are expressed. If the parents carry different alleles at a particular locus, this leads to heterozygous patterns in the sporophyte, from which the number of subunits can be deduced.

No evidence of linkage was observed between Gpi-2 and Pgm-1 in P. undulatum ( $n=11$ chromosomes) in this study. Due to the low number of genetic studies that have been carried out, only one likely case of linkage has been reported until now in bryophytes: between two nicotin-acid auxotrophs in Sphaerocarpus donnellii (Schieder, 1973).

\section{Isozyme numbers and gene duplications}

Electrophoretic studies on the number of gene loci coding for particular enzyme systems have revealed that in most higher plants the minimum number and subcellular distribution of isozymes of many enzymes are highly conserved (Gottlieb, 1982). Most diploid flowering plants have two isozymes for each glycolytic enzyme and for enzymes of the pentose phosphate pathway. This also holds for the moss genus Plagiothecium. The number of isozymes generally reflects the number of subcellular compartments (plastids and cytosol) in which the same catalytic reaction is required. An increase in isozyme numbers can result from duplication of the entire genome via polyploidization or from gene duplication.

The three PGM activity zones observed in $P$. undulatum vary independently from each other (see Figs 2 and 3), so they are probably encoded by different genes. This increase in PGM isozyme number could be the result of a polypoloidization. The chromosome number in the investigated population of $P$. undulatum is 11 (Hofman, 1988b), as in many other species of this genus (Inoue \& Iwatsuki, 1987; Hofman, $1988 \mathrm{~b})$. Therefore a recent genome duplication in this species seems out of the question. Chromosome numbers of 6-8 are reported frequently in mosses (Ramsay, 1983), and a chromosome number of 11 in Plagiothecium and many other pleurocarps may represent an ancient polyploidization [patterns of change in chromosome number in mosses include both polyploidy and aneuploidy (Ramsay, 1983)]. However, in all other Plagiothecium species studied only the usual two PGM isozymes occur. A gene duplication, followed by mutation at one locus seems to be the simplest explanation of the observed PGM banding patterns in $P$. undulatum. Gene duplication has played an important role in increasing the minimum isozyme number and has been extensively reported in several diploid plant species, for example in Clarkia (Soltis et al., 1987), Scabiosa columbaria (R. van Treuren \& R. Bijlsma, personal communication) as well as in polyploids of Dactylis glomerata (Lumaret, 1986). Possible cases of gene duplication in bryophytes are discussed by De Vries et al. (1989) and by Wyatt et al. (1989).

Duplication of the Icd-locus in Plagiothecium is still questionable. In the whole genus this enzyme system displays either a single band or three bands of activity (also in diploid sporophytes). The three banded phenotype may actually be the product of two dimeric isozymes which are still homologous enough to form heterodimeric bands when they carry different alleles. This pattern would then be the result of gene duplication, as no hybrid molecules are formed between gene products active in different cell compartments. The presumptive $I c d-2$ locus is monomorphic (b) in the Asserbos population, and the presumptive Icd-1 locus is diallelic ( $a$, the apomorphic state or b, the plesiomorphic state). This would explain why the a/a genotype (single fast band) has never been observed, although more than 1000 individuals have been sampled in this population (A. Hofman, in preparation). The above interpretation is represented in Fig. 3, and explains the Mendelian segregation (1:1) of the singleand three-banded phenotypes in the progeny from capsule 2. Duplications for the cytosolic NADPdependent ICD has also been reported in Laya (Gottlieb, 1987), Stephanomeria diegensis (Gallez \& Gottlieb, 1982), soybean (Yong et al., 1981) and maize (Goodman et al., 1980). Another explanation of the observed segregation for Icd is the attachment of charged satellite molecules following translation (posttranslational modification), resulting in a multiple banding pattern. This is a common feature of ICD. It is unlikely, however, that this phenomenon would occur in only a few plants, as growing, grinding and electrophoretic conditions were uniform for all sporelings. It is possible that Icd is monomorphic in all sporelings, but that their parents differed for a modifying gene which affects the attachment of charged molecules. More research would be needed to be able to choose between these alternative explanations.

In respect to the conservative number and subunit structure of isozymes, it can be stated that bryophytes show much resemblance to higher plants. The genetic basis of observed electrophoretic variance, as demonstrated in this study, warrants the use of allozymes as markers, for example the analysis of population structure and mating system in future studies (A. Hofman, in preparation.)

\section{Acknowledgements}

We wish to thank R. Bijlsma, A. Kamping and K. Wolff for their helpful comments on this manuscript. This study was supported by the Foundation for Fundamental Biological Research (BION), which is subsidized by The Netherlands Organization for the Advancement of Scientific Research (NWO). 


\section{References}

ALlsopP, A, AND MITRA, G. C. 1958. The morphology of protonema and bud formation in the Bryales. Ann. Bot., 22, 95-115.

ASHTON, N. W., BOYD, P. J., COVE, D. J. AND KNIGHT, C. D. 1988. Genetic analysis in Physcomitrella patens. In: Glime, J. M. (ed.) Methods in Bryology, Hattori Botanical Laboratory, Nichinan, Japan, pp. 59-72.

CovE, D. J. 1983. Genetics of Bryophyta. In: Schuster, R. M. (ed.) New Manual of Bryology, Vol. I, Hattori Botanical, Laboratory, Tokyo, Japan, pp. 222-231.

DE VRIES, A., BRAMER, J. P. J., VAN ZANTEN, B. O., HOFMAN, A. AND BIJLSMA, R. 1989. Allozyme variation in populations of four Racopilum species, including the polyploid $R$. tomentosum. Lindbergia, 15, 47-59.

GALLEZ, G, P. AND GOTTLIEB, L. D. 1982. Genetic evidence for the hybrid origin of the diploid plant Stephanomeria diegensis. Evolution, 36, 1158-1167.

GOODMAN, M. M., STUBER, G. W., NEWTON, K. AND WEISSINGER, H. H 1980. Linkage relationships of 19 enzyme loci in maize. Genetics, 96, 697-710.

GotTlieB, L. D. 1982. Conservation and duplication of isozymes in plants. Science, 216, 373-380.

GOTTLIEB, L. D. 1987. Phosphoglucomutase and isocitrate dehydrogenase gene duplications in Laya (Compositae). Am. J. Bot., 74, 9-15.

GRIMSLEY, N. H., ASHTON, N. w. AND COVE, D. J. 1977a. The production of somatic hybrids by protoplast fusion in the moss, Physcomitrella patens. Molec. Gen. Gene., 154, 97-100.

GRIMSLEY, N. H., ASHTON, N. W. AND COVE, D. J. 1977 b. Complementation analysis of auxotrophic mutants of the moss, Physcomitrella patens, using protoplast fusion. Molec. Gen. Genet., 155, 103-107.

GRIMSLEY, N. H., FEATHERSTONE, D. R., COURTICE, G. R. M., ASHTON, N. W. AND COVE, D. J. 1980. Somatic hybridization following protoplast fusion as a tool for the genetic analysis of development in the moss, Physcomitrella patens. In: Ferenzy, L. and Farkas, G. L. (ed.) Advances in Protoplast Research. Proceedings of the 5th International Protoplast Symposium, Szeged, Hungary, Pergamon Press, Oxford, pp. 363-376.

HOFMAN, A. 1988a. Starch gel electrophoresis: A tool for studying the phylogenetic systematics and population genetics of mosses. In: Glime, J. M. (ed.) Methods in Bryology, Hattori Botanical Laboratory, Nichinan, Japan, pp. 353-358.

HOFMAN, A. 1988 b. A preliminary survey of allozyme variation in the genus Plagiothecium (Plagiotheciaceae, Bryopsida). J. Hattori Bot. Lab., 64, 143-150.

INNES, D. J. 1990. Microgeographic genetic variation in the haploid and diploid stages of the moss Polytrichum juniperinum Hedw. Heredity, 64, 331-340.

INOUE, s. AND IWATSUKI, z. 1987. Cytotaxonomic studies of PlagiotheciumB.S.G. and its related genera. J. Hattori Bot. Lab., 63, 453-471.

LONGTON, R. E. 1976. Reproductive biology and evolutionary potential in bryophytes. J. Hattori Bot. Lab., 41, 205-223. LONGTON, R. E. AND SCHUSTER, R. M. 1983. Reproductive biology. In: Schuster, R. M. (ed.) New Manual of Bryology, Vol. 1, Hattori Botanical Laboratory, Nichinan, Japan, pp. 386-462.

LUMARET, R. 1986. Doubled duplication of the structural gene for cytosolic phosphoglucose isomerase in the Dactylis glomerata L. polyploid complex. Mol. Biol Evol., 3, 499-521.

MEAGHER, T. R. AND SHAW, J. 1990. Clonal structure in the moss, Climacium americanum Bird. Heredity, 64, 233-238.

MUGGOCH, H. AND WALTON, J. 1942. On the dehiscence of the antheridium and the part played by surface tension in the dispersal of spermatocytes in Bryophyta. Proc. R. Soc. Lond. B. Biol. Sci., 130, 448-461

MURASHIGE, T. AND SKOOG, F. 1962. A revised medium for rapid growth and bioassays with tobacco tissue cultures. Physiol. Plant, 15, 473-497.

NEWTON, M. E. 1972. Sex-ratio differences in Mnium hornum Hedw. and M. undulatum Sw., in relation to spore germination and vegetative regeneration. Ann. Bot., 36, 163-178

RAMSAY, H. P. 1983. Cytology of mossses. In: Schuster, R. M. (ed.) New Manual of Bryology, Vol. 1, Hattori Botanical Laboratory, Nichinan, Japan, pp. 149-221.

SCHIEDER, o. 1973. Untersuchungen an Nicotinsäureauxotrophen Stämmen von Sphaerocarpus donnelli Aust. Zeit. Pflanzenphysiol., 70, 185-189.

SMith, A. J. E. 1978. The Moss Flora of Britain and Ireland. Cambridge University Press, Cambridge.

SOKAL, R. R. AND ROHLF, F. J. 1981. Biometry, 2nd edn, W. H. Freeman and Co., San Francisco.

SOLTIS, P. S., SOlTIS, D. E. AND GOTTLIEB, L. D. 1987. Phosphoglucomutase gene duplications in Clarkia (Onagraceae) and their phylogenetic implications. Evolution, 41, 667-671.

STONEBURNER, A. 1979. Fruiting in relation to sex ratios in colonies of Pleurozium schreberi in Northern Michigan. Michig. Botanist, 18, 73-81

TOUW, A. AND RUBERS, w. v. 1989. De Nederlandse bladmossen. Sitchting Uitgeverij Koninklijke Nederlandse Natuurhistorische Vereniging, Utrecht, The Netherlands.

VON WETTSTEIN, F. 1923. Kreuzungsversuche mit multiploiden Moosrassen. Biol. Zentralbl., 43, 71-82.

VON WETTSTEIN, F. 1924. Kreuzungsversuche mit multiploiden Moosrassen II. Biol. Zentralbl., 44, 145-168.

WYATT, R., ODRZYKOSKI. 1. J. AND STONEBURNER, A. 1989. High levels of genetic variation in the moss Plagiomnium ciliare. Evolution, 43, 1085-1096.

YONG, H. S., CHAN, K. L., MAK, C. AND DHALIWAL, s. s. 1981. Isocitrate dehydrogenase gene duplication and fixed heterophenotype in the cultivated soybean Glycine max. Experientia, 37, 130.

ZIELINSKY, R. 1984. Electrophoretic evidence of cross-fertilization in the monoecious Pellia epiphylla, $n=9$. J. Hattori Bot. Lab., 56, 255-262.

ZIELINSKY, R. 1986. Cross-fertilisation in the monoecious Pellia borealis, $n=18$, and spatial distribution of two peroxidase genotypes. Heredity, 56, 299-304. 